\title{
Effectiveness of social media marketing in the restaurant industry
}

\author{
Manalo, Sherly $\square$
}

Lyceum of the Philippines University - Batangas;

Westmead International School, Philippines (sherlycastillomanalo@gmail.com)

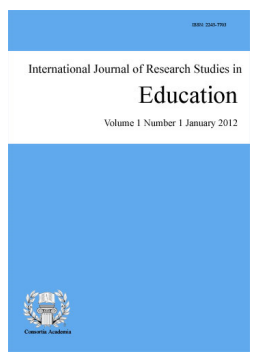

ISSN: 2243-7703 Online ISSN: 2243-7711

OPEN ACCESS

\section{Abstract}

Technological innovation started to progress even more, and because of this, business corporations saw an opportunity and use social media to promote their business. The objectives of this study are to; present the profile of the respondents in terms of age, gender, civil status, educational attainment, work position and residence, and frequency or time spent on social media; determine the effectiveness of social media in marketing in terms of customer generation, profit growth, customer satisfaction and loyalty; and the significant difference of the responses. Descriptive type of research was utilized in the study. The result shows that respondents are 21 to 30 years old, female and living in the city. Majority of customer respondents are single and had their secondary education, while restaurant owners are married, had their baccalaureate degree and in an executive position. They can access their social media account every day and see it as an effective means to generate customer, profit growth, customer satisfaction and loyalty. There's no significant difference from the responses in terms of in terms of market share, sales customer services and satisfaction, and customer loyalty. Customers have significantly higher problems encountered on social media compared to owners. The restaurant owners should utilize the use of social media to enhance its brand image and popularity, as a source of information for improving a business and creating new product, and to generate interaction that can maintain a good and long-term relationship with customers. The action plan proposed by the researcher can be utilized by the restaurant owners.

Keywords: marketing; social media; hospitality; technology; restaurant 


\section{Effectiveness of social media marketing in the restaurant industry}

\section{Introduction}

In the hospitality industry, marketing is very important, and the development of technology introduced a new way to reach the market (CSPOnline, 2016). As part of technological innovation, social media (SM) became popular and turns into a powerful tool in conveying information (Derani \& Naidu, 2015). It is the most appropriate tool that can be used to have a successful presence (Koroma, 2012). The marketing trends have changed. Now, the consumers can communicate with other consumers using SM (Assebov \& Khurana, 2012). Because of this, business needs to change as well. People interact, gather, and distribute information online. With the use of social media marketing (SMM), entrepreneurs can understand the customers better. Companies can also use SM to broadcast live in their events. They can also create sites and applications. Those actions can closer the bond between customers and the company, which in turn, will result to a good profit (Kim \& Ko, 2010).

A study conducted by Sparks and Browning (2011) stated that SMM is not effective in driving price-based promotions. However, according to Debono (2013), SMM is more effective in generating brand benefits rather than generating potential business opportunities if managed in a professional manner. The purpose of this study is to determine the effectiveness of social media marketing in the industry. The outcome of this research can be utilized by the restaurant owners as a tool in order for them to the extent of the activity that they would implement and execute to maximize their marketing potential.

\subsection{Objectives of the study}

This study will determine the marketing effectiveness of social media in the hospitality industry in Batangas City. More specifically, it will show the respondents' age, gender, civil status, educational attainment, work position and residence and frequency/time spent on it. It will also determine the effectiveness of social media in marketing in terms of customer generation, profit growth, customer satisfaction and loyalty. The study will further test the significant difference of the respondents and effectiveness of social media marketing; and propose marketing strategies for the hospitality industry.

\section{Theoretical framework}

Customer generation - Travelers know a place without being there physically, through SM. This increase the first time and return customers of businesses. Forty percent of travelers use SM while 80 percent use review sites to know the opinions of other people. In US, $82 \%$ of travelers have done the same (Fotis, Buhalis, \& Rossides, 2012). By using SM and review sites, travelers will know the firsthand experience of other travelers. This can be a deciding factor for them, whether to purchase the product or not. Review sites have rating scale. Establishments achieve a high rating score by satisfying customers. After receiving a good service, customers will share his or her good experience in SM and give a high rating score to the establishment. This high rating score will attract customers that want to experience the same good experience mentioned by the previous customers. There is a $13.5 \%$ probability that potential customer will visit a business with just 1-point increase in its average rating (Anderson, 2012)

Customer service - The modern-day consumer wants to access information and be able to ask questions at any time of the day. They need to be able to find and purchase a product or service that suits them and their needs immediately. With a declining brand and property loyalty (Singh \& Chekitan, 2014), and an increased amount of competition, establishments are beginning to lose their relationships with their guests (Green, 2006; Torres \& Kline, 2013). If they are unsatisfied with the service, they will speak up and tell people what happened. 
Effectiveness of social media marketing in the restaurant industry

Internet allows consumers to bond with others, and this make them feel bolder to challenge marketers.

Information is important in the industry (Lee, Verma, \& Roth, 2015). It can be gathered from the customers through SM. Customers are willing to share information because this is their opportunity to be heard. This is also an opportunity for businesses to learn more about the guests' wants and needs. Those information's can be used to provide a better service for the customers. Responding to customers' post will make them feel that they made a contribution to the company. Marketing organizations use SM as a medium to reach customers. Postings can initiate a response from them. It is easier and more accessible for customers to say their opinions. It can also be the chance for establishments to clarify or remove any bad impression tagged to their name (Bhanot, 2012). Individuals feel free on the internet, it allows them the chance to express themselves and mostly without consequences making it one of the factors that render SMM unpredictable and uncontrollable because no one can stop people from expressing their thoughts. Because of the SM, there is a consistency in price and quality of the products. This will also increase the value of the company and the volume of customer that wants to shop.

Customer loyalty - Online brand loyalty is shaped through: the company's conversational engagement with its target audience, by listening and researching customer's behavioral patterns (Zucal, 2012), embracing customer's requirements to deliver what they want, providing fast responses, and excellent online customer quality service. A successful brand retains satisfied and loyal customers, which are key influencers in generating positive word-of-mouth advertising and respond more favorably to the brand than non-loyal ones (Callarisa, García, Cardiff, \& Roshchina, 2012).

\subsection{Problems}

While social media engagement is necessary to a business for branding and communication, it can also work against a business if used inappropriately. This statement is supported by the study of; Coombs and Holladay (2012); Kietzmann, Hermkens, McCarthy, and Silvestre (2011); and Iacianci (2015). With the emergence of the internet, privacy starts to become an issue (Osatuyi, 2015). Akram and Kumar (2017) listed down the negative effect of SM on business. It includes people being allowed to post their feelings which can be negative and harm the business. There's also cyber harassing which is very common for young people.

SM change the way people share and convey information, but it can also result to a long-term negative aftermath. In SM, malicious and negative people also exist. Those people aim to harm the reputation of a company. Sometimes, they post negative things that intend to spread bad vibe to one's brand. There are also online threats and cybercriminals. While SM engagement is necessary to a business for branding and communication, it can also work against a business if used inappropriately. This statement is supported by the study of; Coombs and Holladay (2012); Kietzmann, Hermkens, McCarthy, and Silvestre (2011); and Iacianci (2015). SM provides a whole new platform for which it builds or destroys an industry.

\section{Findings}

After tabulating all the data gathered, table 1 shows the percentage distribution of customers and managers profile. In terms of civil status, the result indicates that 72.20 percent of the customers are single while 60 percent of the management staff are already married. In terms of educational attainment, the respondents have slightly higher number of High school Graduate from 40.30 percent of the customers and Bachelor's Degree from 90 percent of the management staff. It also shows that the largest number of customers is students with 40.90 percent while the least are self-employed with 3.40 percent. For the management staff, most of them have an execute position with 50 percent. With respect to their origin or residence, the greater number of respondents is from the city both customers with 71.70 percent and the management staff with 90 percent.

The table 2 shows the percentage distribution of the Restaurants profile. It revealed that within the criteria, most of the restaurants in Batangas City is a family restaurant. It also showed that those restaurants are still young with 1 to 3 years of operation. Almost all of them put up their restaurants within the city where there's a 
Manalo, S.

lot of foot traffic. They are taking advantage of social media and started to use it from 2011 to 2016.

\section{Table 1}

Percentage distribution of the respondents' profile

\begin{tabular}{|c|c|c|}
\hline Profile variables & Customers \% & Owners \% \\
\hline \multicolumn{3}{|l|}{ Age } \\
\hline Below 20 years old & 36.7 & 0 \\
\hline $21-30$ & 39.4 & 40 \\
\hline $31-40$ & 13.3 & 20 \\
\hline $41-50$ & 6.1 & 30 \\
\hline $51-60$ & 2.2 & 10 \\
\hline 61 above & 2.2 & 0 \\
\hline \multicolumn{3}{|l|}{ Gender } \\
\hline Male & 33.9 & 40 \\
\hline Female & 66.1 & 60 \\
\hline \multicolumn{3}{|l|}{ Civil status } \\
\hline Single & 71.1 & 30 \\
\hline Married & 25.6 & 60 \\
\hline Separated & 1.1 & 0 \\
\hline Widowed & 2.2 & 10 \\
\hline \multicolumn{3}{|l|}{ Educational attainment } \\
\hline Elementary Graduate & 0.6 & 0 \\
\hline High School Graduate & 40 & 0 \\
\hline Vocational & 15 & 10 \\
\hline Bachelor's Degree & 39.4 & 90 \\
\hline Master's Degree & 5 & 0 \\
\hline \multicolumn{3}{|l|}{ Positions } \\
\hline Executive Manager & 7.8 & 50 \\
\hline Entry-Level Management & 11.1 & 30 \\
\hline Staff Positions & 18.3 & 20 \\
\hline Contractors & 12.7 & 0 \\
\hline Self-employed & 3.8 & 0 \\
\hline Unemployed & 6.1 & 0 \\
\hline Student & 40 & 0 \\
\hline \multicolumn{3}{|l|}{ Residence } \\
\hline Urban & 71.7 & 90 \\
\hline Rural & 28.3 & 10 \\
\hline
\end{tabular}

Table 2

Percentage distribution of the business profile

\begin{tabular}{lcc}
\hline & Profile variables & Percentage (\%) \\
\hline Fine Dining & Classification of restaurant & 10 \\
Fine Casual & & 10 \\
Ethnic & & 10 \\
Family & Year of operation & 70 \\
\hline & & 10 \\
1 year and below & & 50 \\
3-5 years & & 10 \\
10 years and above & Location of the business & 30 \\
\hline & & 70 \\
Within the city & & 30 \\
\hline km away from the city & & 20 \\
Year when Social Media Marketing was introduced in the business & 80 \\
\hline
\end{tabular}

Table 3 has shown the different forms of social media being use by the respondents and the how often they are using it. Based on the result, 90 percent of the owners and 96.11 percent of the customers are using Facebook. This proved that Facebook is the most popular and commonly used social media today. Both respondents choose 
Instagram with 55 percent over Twitter that received 47.22 percent even though the latter has been around the internet longer than the other.

The other social media being used by the customers are; other social media which includes any other social media that is not mentioned in this study, 14.44 percent; personal website, 21.67 percent; TripAdvisor, 18.89 percent; Linked In, 16.11 percent; Travel Blogs, 14.44 percent; e-newsletter and Agoda, 13.33 percent; and Myspace, 12.22 percent. On the other hand, the restaurant uses; personal website, 30 percent; Travel Blogs and TripAdvisor, 10 percent; and E-newsletters, Agoda, Myspace, Linked in and Twitter, 0 percent. All of the businesses have accounts in social media sites and use it for different reasons.

Table 3

Forms of social media and frequency of use

\begin{tabular}{lcccc}
\hline & \multicolumn{2}{c}{ Customers } & \multicolumn{2}{c}{ Owners } \\
\cline { 2 - 5 } & $\mathrm{f}$ & \%/WM & $\mathrm{f}$ & $\% / \mathrm{WM}$ \\
\hline Facebook & 173 & 96.11 & 9 & 90 \\
Instagram & 99 & 55.00 & 4 & 40 \\
Twitter & 85 & 47.22 & 0 & 0 \\
Linked In & 29 & 16.11 & 0 & 0 \\
MySpace & 22 & 12.22 & 0 & 0 \\
Agoda & 24 & 13.33 & 0 & 0 \\
Personal Website/ Blogs & 39 & 21.67 & 3 & 30 \\
Travel Blogs & 26 & 14.44 & 1 & 10 \\
E newsletter & 24 & 13.33 & 0 & 0 \\
TripAdvisor & 34 & 18.89 & 1 & 10 \\
Others & 65 & 36.11 & 0 & 0 \\
\hline *Type of contents posted by business and rate the frequency of posting it & & & \\
\hline Photos & 3.33 & Often & 2.9 & Often \\
Links & 2.47 & Sometimes & 2.0 & Sometimes \\
Status & 2.91 & Often & 2.8 & Often \\
Album & 2.61 & Often & 2.2 & Sometimes \\
Video & 2.68 & Often & 2.1 & Sometimes \\
Others & 2.18 & Sometimes & 1.2 & Never \\
\hline Frequency spent in social media & & & & \\
\hline Everyday & 133 & 73.9 & 4 & 40 \\
Weekly & 33 & 18.3 & 1 & 10 \\
Monthly & 6 & 3.3 & 3 & 30 \\
Annually & 8 & 4.4 & 2 & 20 \\
\hline How fast do the businesses respond to online inquiry and/or comments? & & & & \\
\hline Immediately after it is posted & 48 & 27.3 & 3 & 30 \\
Within an hour & 43 & 24.4 & 0 & 0 \\
Within the day & 43 & 24.4 & 2 & 20 \\
Within a few days & 31 & 17.6 & 4 & 40 \\
Not at all & 15 & 8.5 & 1 & 10 \\
\hline Nore Len & & & \\
\hline
\end{tabular}

Note. Legend: $3.50-4.00=$ Always; $2.50-3.49=$ Often; $1.50-2.49=$ Sometimes; $1.00-1.49=$ Never.

Restaurants often post photos of their food and customers notice it, according to their response to the survey. According to Corradini (2019), the industry favored foods that are appealing to the eyes with its color. The appearance of the food in the photos attracts customers and this is the reason of restaurants in posting it. Status and comments are often posted with photos, links, and videos with it. Links will connect the user to a different website and is not commonly used by the restaurants. On the other hand, the response of the restaurants and customers are different for albums, videos, and other contents. Customers often see it posted by restaurants but the respondent restaurants are posting it sometimes. It can infer that the contents seen be the customers are not posted by the restaurant respondents and from another popular brand. Different types of contents attract people to view the account. Most of the people want something that pleases the eye, which is the reason images is very popular.

The finding also implies that majority of both respondents use social media every day. An article by Metev (2020) break down length of time people spend in social media; average US adults, 38 minutes; and 16-24 years 
old, 3 hours. In 2017, people are in social media for 134 minutes per day. Desktop users spend 55.4 minutes per day engaging in Facebook (Adler, 2014). Some people use social media per week with 73.9 and 40 percent, while others use it every month or annually. Customers might see it as an option whether to use social media or not. Restaurant businesses on the other hand need to actively use their account especially if they want to take advantage of it for marketing. In order for online interactions to be successful, there is a need to focus on speed of response to build trust and strong communications with customers so that they can adjust their cost to deliver precisely what the customer wants.

The table also showed the speed of responses from the restaurant business to the online inquiries. It shows that majority of the customers received: immediate response, 27.3 percent; within an hour and a day, 24.4 percent; within a few days, 17.6 percent; and not at all, 8.5 percent. On the other hand, restaurant businesses respond to online inquiries: within a few days, 40 percent; immediately, 30 percent; within the day, 20 percent; and not at all, 10 percent. The responses of both respondents are different from the other. Customers receive response from businesses, not necessarily the restaurant respondents, as soon as restaurant possibly can. The restaurants that the customers are talking about might be franchise, have an active marketing team, or using a chatbot for auto response.

It is necessary for businesses to post frequently on their social media sites to ensure that potential customers remain aware of the company. If companies strive success in social media, they must post consistently (Odden, 2011). Based on the result, the researcher can infer that the restaurant respondents don't have high expectation with social media or don't have enough time and resources to handle the online marketing.

\section{Table 4}

Effectiveness of social media with regards to market share/customer generation

\begin{tabular}{|c|c|c|c|c|c|c|c|c|c|}
\hline \multirow{2}{*}{ Items } & \multicolumn{3}{|c|}{ Customer } & \multicolumn{3}{|c|}{ Owners } & \multicolumn{3}{|c|}{ Over-all } \\
\hline & WM & VI & $\mathrm{R}$ & WM & VI & $\mathrm{R}$ & WM & VI & $\mathrm{R}$ \\
\hline $\begin{array}{l}\text { Social media can be an effective means to enhance brand } \\
\text { image and popularity }\end{array}$ & 3.35 & $\mathrm{E}$ & 4 & 3.4 & $\mathrm{E}$ & 1.5 & 3.38 & $\mathrm{E}$ & 1 \\
\hline $\begin{array}{l}\text { Social media is an effective way for news and updates to } \\
\text { reach consumers who would have otherwise never heard } \\
\text { of the business. }\end{array}$ & 3.43 & $\mathrm{E}$ & 1 & 3.3 & $\mathrm{E}$ & 4 & 3.36 & $\mathrm{E}$ & 2 \\
\hline $\begin{array}{l}\text { Social media is an effective way for customers/people } \\
\text { from other province or abroad that are not familiar with } \\
\text { the place in choosing a business or establishment to visit } \\
\text { before they even arrived in the destination. }\end{array}$ & 3.39 & $\mathrm{E}$ & 2 & 3.3 & $\mathrm{E}$ & 4 & 3.35 & $\mathrm{E}$ & 3 \\
\hline $\begin{array}{l}\text { Social media is an effective way for customer to be aware } \\
\text { of the product being offered by businesses. }\end{array}$ & 3.38 & $\mathrm{E}$ & 3 & 3.3 & $\mathrm{E}$ & 4 & 3.34 & $\mathrm{E}$ & 4 \\
\hline $\begin{array}{l}\text { Social media can influence the customer's purchasing } \\
\text { decisions. }\end{array}$ & 3.24 & $\mathrm{E}$ & 6 & 3.4 & $\mathrm{E}$ & 1.5 & 3.32 & $\mathrm{E}$ & 5 \\
\hline $\begin{array}{l}\text { Social media as a reliable means to explore the culture, } \\
\text { views and lifestyles that influence consumer behavior. }\end{array}$ & 3.28 & $\mathrm{E}$ & 5 & 3.2 & $\mathrm{E}$ & 6 & 3.24 & $\mathrm{E}$ & 6 \\
\hline $\begin{array}{l}\text { Reading good feedbacks from others through social } \\
\text { media, customers are encouraged to try new products } \\
\text { being offered. }\end{array}$ & 3.15 & $\mathrm{E}$ & 8 & 3.1 & $\mathrm{E}$ & 7 & 3.13 & $\mathrm{E}$ & 7 \\
\hline $\begin{array}{l}\text { The customer can access the business's account with ease } \\
\text { using any gadgets with internet connection. }\end{array}$ & 3.23 & $\mathrm{E}$ & 7 & 2.9 & $\mathrm{E}$ & 8 & 3.06 & $\mathrm{E}$ & 8 \\
\hline Composite mean & 3.31 & $\mathrm{E}$ & & 3.24 & $\mathrm{E}$ & & 3.27 & $\mathrm{E}$ & \\
\hline
\end{tabular}

Table 4 shows that both respondents perceived that social media is effective with regards to market share or customer generation and garner a composite mean of 3.27. They perceived that social media is an effective means to enhance brand image and popularity with a weighted mean of 3.38. Businesses use social media to be known by customers. Nassar affirmed that social media is a pronounced method to boost the reputation of a business (Nassar, 2012). This study also confirmed Nassar's conclusion. Nowadays, many small businesses rely on social media to be recognized. With repeated exposure, they will achieve it. This is an opportunity to remind them that the business establishment and the product exist. 
Social media is also an effective way for news and updates to reach consumers who would have otherwise never heard of the business and way for people from other provinces or abroad that are not familiar with the place in choosing a business or establishment to visit before they even arrived in the destination with a weighted mean of 3.36, and 3.35, respectively. News and updates can be posted in social media. Some can even receive discount offers from the business. Possible cancelation or closing of the establishment for specific dates can help customers in deciding whether to visit the restaurant or not.

Customers go to social media sites before making a travel related decision. Receiving good reviews from past customers can attract new customers (Kim \& Ko, 2010). Shared photos and videos from previews customers can also be an opportunity to encourage people to visit the restaurant. Rathonyi said that the industry can accept this opportunity to draw in customer (Rathonyi, 2013). The respondents still see the effective means of using social media in any gadgets with internet with the weighted mean of 3.06. They position this at last part of the list. Mobile apps can now be used as a tool for faster and better communication even without the use of internet. With connection to this, Bredican and Vigar-Eliss (2014) mentioned that this will benefit the industry by creating brand awareness, maintaining loyalty of the customers and building good relationships. This can be inferred that the type of gadget is used to view social media is not as important as the content of the post or message the establishments wants to convey.

Table 5 shows that both respondents perceived that social media is effective with regards to sales/profit growth and garner a composite mean of 3.02. The respondents perceived that internet access and social media is now a powerful marketing tool in a restaurant/hotel business with 3.40 as its weighted mean. Word of mouth is the most powerful promotional tool according to Verma, Stock, and McCarthy (2012). Social media is a virtual version of word of mouth and therefore can be said that social media is powerful marketing tool.

\section{Table 5}

Effectiveness of social media with regards to sales/profit growth

\begin{tabular}{|c|c|c|c|c|c|c|c|c|c|}
\hline \multirow{2}{*}{ Items } & \multicolumn{3}{|c|}{ Customer } & \multicolumn{3}{|c|}{ Owners } & \multicolumn{3}{|c|}{ Over-all } \\
\hline & WM & VI & $\mathrm{R}$ & WM & VI & $\mathrm{R}$ & WM & VI & $\mathrm{R}$ \\
\hline $\begin{array}{l}\text { Internet access and social media is now a powerful } \\
\text { marketing tool in a restaurant/hotel business. }\end{array}$ & 3.40 & $\mathrm{E}$ & 1 & 3.4 & $\mathrm{E}$ & 1 & 3.40 & $E$ & 1 \\
\hline $\begin{array}{l}\text { Social media helps largely in increasing sales of products } \\
\text { and services being offered. }\end{array}$ & 3.27 & $\mathrm{E}$ & 2 & 3.0 & E & 2.5 & 3.13 & $\mathrm{E}$ & 2 \\
\hline $\begin{array}{l}\text { Business grow its sales and profit at a maximum possible } \\
\text { rate due to the ability to attract new customers. }\end{array}$ & 3.14 & $\mathrm{E}$ & 4 & 3.0 & $\mathrm{E}$ & 2.5 & 3.07 & $\mathrm{E}$ & 3 \\
\hline $\begin{array}{l}\text { One click away of an application leads the customer to } \\
\text { the nearest restaurant that they may want to visit. }\end{array}$ & 3.23 & $\mathrm{E}$ & 3 & 2.8 & $\mathrm{E}$ & 5.5 & 3.02 & $\mathrm{E}$ & 4 \\
\hline $\begin{array}{l}\text { Menu items that gives high profit contribution, when } \\
\text { merchandized in social media gives a significant sales } \\
\text { contribution. }\end{array}$ & 3.06 & E & 6 & 2.9 & E & 4 & 2.98 & $\mathrm{E}$ & 5 \\
\hline $\begin{array}{l}\text { With different promo's/discounts in social media, } \\
\text { customers are encouraged to increase their purchase. }\end{array}$ & 3.11 & E & 5 & 2.8 & E & 5.5 & 2.96 & E & 6 \\
\hline Social media boost the customer's transaction count. & 2.91 & $\mathrm{E}$ & 7 & 2.3 & LE & 7 & 2.61 & $\mathrm{E}$ & 7 \\
\hline Composite mean & 3.16 & $\mathrm{E}$ & & 2.89 & $\mathrm{E}$ & & 3.02 & $\mathrm{E}$ & \\
\hline
\end{tabular}

Social media also an effective help in increasing sales of products and services being offered with a weighted mean of 3.13. After the exposure to social media, customers become curious to what that product is all about. It results to the increase of sales of products and services being offered. These findings which conclude that less than half of the customers purchase the item with the influence of shares from a social media site. Business grows its sales and profit at a maximum possible rate due to the ability to attract new customers with weighted mean of 3.07. People trust what other people experienced and learn from it. People not only learn from it but based their expectations so that they can avoid the risk of being disappointed (Fotis et al., 2012). Based on past studies, it can be inferred that businesses tag or associated with bad incident will be avoided by customers vice versa. Social media is still an effective means to boost the customer's transaction count ranked with a 
Manalo, S.

weighted mean of 2.61. Customers will be curious about the products being offered but that doesn't always turn into a transaction. The overall rank might view it as effective but restaurants see it otherwise. Restaurants considered it as less effective. The reason behind that is still unclear.

Table 6 shows that both respondents perceived that social media is effective with regards to customer service and satisfaction with a composite mean of 2.98. With a weighted mean of 3.17, they noticed that social media is an effective source of information for improving a business and creating new product that can be accepted by customers. Social media is the place customers talked about what they need, want, like or dislikes in real time without considering if it is still business hours or not. This can increase the data business gain (Bhanot, 2012). Even Dina and Sabou (2012) agree that internet is the main source of information. Even with this data, restaurants sometimes neglect that information and focus more on social media's accessibility.

Social media is effective in interacting and connecting to people anytime from anywhere with internet connection with a weighted mean with 3.15. Customer can access the services without travelling to the establishment for a face to face meeting (Faria \& Elliot, 2012). This will be easier for the customers to choose the services and product they will purchase. Restaurants can now also engage with customers in creative ways using different social media sites, weighted mean of 3.14. Any type of content can be posted as long as it doesn't break any privacy or copyright law.

\section{Table 6}

Effectiveness of social media with regards to customer service and satisfaction

\begin{tabular}{|c|c|c|c|c|c|c|c|c|c|}
\hline \multirow{2}{*}{ Items } & \multicolumn{3}{|c|}{ Customer } & \multicolumn{3}{|c|}{ Owners } & \multicolumn{3}{|c|}{ Over-all } \\
\hline & WM & VI & $\mathrm{R}$ & WM & VI & $\mathrm{R}$ & WM & VI & $\mathrm{R}$ \\
\hline $\begin{array}{l}\text { Social media is an effective source of information for } \\
\text { improving a business and creating new product that can } \\
\text { be accepted by customers. }\end{array}$ & 3.35 & $\mathrm{E}$ & 1 & 3.00 & $\mathrm{E}$ & 3 & 3.17 & $E$ & 1 \\
\hline $\begin{array}{l}\text { Social media has no hours of business, everyone can } \\
\text { interact and connect at anytime from anywhere with an } \\
\text { internet connection. }\end{array}$ & 3.19 & $\mathrm{E}$ & 3 & 3.10 & $\mathrm{E}$ & 1 & 3.15 & $\mathrm{E}$ & 2 \\
\hline $\begin{array}{l}\text { With different social media sites, business can engage } \\
\text { with customers in creative ways. }\end{array}$ & 3.27 & $\mathrm{E}$ & 2 & 3.00 & $\mathrm{E}$ & 3 & 3.14 & $\mathrm{E}$ & 3 \\
\hline $\begin{array}{l}\text { Social media tends to increase the boldness/courage of } \\
\text { customers and freely convey their feedback about a } \\
\text { business. }\end{array}$ & 3.14 & $\mathrm{E}$ & 5 & 3.00 & $\mathrm{E}$ & 3 & 3.07 & $\mathrm{E}$ & 4 \\
\hline $\begin{array}{l}\text { Social media can be used to immediately respond to } \\
\text { complaints and misunderstanding between business and } \\
\text { customers. }\end{array}$ & 3.18 & $\mathrm{E}$ & 4 & 2.90 & $\mathrm{E}$ & 5 & 3.04 & $\mathrm{E}$ & 5 \\
\hline $\begin{array}{l}\text { Through the company's social media account, the } \\
\text { customer have full access on the items offered that } \\
\text { provides ease in product selection. }\end{array}$ & 3.10 & $\mathrm{E}$ & 6.5 & 2.40 & LE & 6 & 2.75 & $\mathrm{E}$ & 6 \\
\hline $\begin{array}{l}\text { Products can be easily availed with no hassle through } \\
\text { online reservation. }\end{array}$ & 3.10 & $\mathrm{E}$ & 6.5 & 2.00 & LE & 7 & 2.55 & $\mathrm{E}$ & 7 \\
\hline Composite mean & 3.19 & $\mathrm{E}$ & & 2.77 & $\mathrm{E}$ & & 2.98 & $\mathrm{E}$ & \\
\hline
\end{tabular}

It is noticeable that restaurants perceived that 'through the company's social media account, the customer have full access on the items offered that provides ease in product selection' and 'products can be easily availed with no hassle through online reservation' are less effective with a weighted mean of 2.75 and 2.55 respectively. Customers might perceive that they can access everything, the restaurant still have the full control on the things that customers can see in their accounts. For example, reservations can lessen the time they have to wait because they already made up their mind what they will purchase or they already book a table before arriving but the restaurant still have the final say whether they are offering reservations or not. Online reservations can only apply to some of the restaurants in Batangas City. 
Effectiveness of social media marketing in the restaurant industry

Table 7

Effectiveness of social media with regards to customer loyalty

\begin{tabular}{|c|c|c|c|c|c|c|c|c|c|}
\hline \multirow{2}{*}{ Items } & \multicolumn{3}{|c|}{ Customer } & \multicolumn{3}{|c|}{ Owner } & \multicolumn{3}{|c|}{ Over-all } \\
\hline & WM & VI & $\mathrm{R}$ & WM & VI & $\mathrm{R}$ & WM & VI & $\mathrm{R}$ \\
\hline $\begin{array}{l}\text { Social Media can generate interaction that can maintain a } \\
\text { good and long-term relationship with customers. }\end{array}$ & 3.16 & E & 6 & 3.80 & HE & 1 & 3.48 & $\mathrm{E}$ & 1 \\
\hline $\begin{array}{l}\text { Good feedbacks by other customer in social media can } \\
\text { create loyal customers/patrons. }\end{array}$ & 3.27 & E & 1.5 & 3.40 & E & 2.5 & 3.34 & $\mathrm{E}$ & 2 \\
\hline $\begin{array}{l}\text { Through social media, there's an opportunity to } \\
\text { strengthen the relationship between a company and its } \\
\text { customers. }\end{array}$ & 3.20 & $\mathrm{E}$ & 4.5 & 3.40 & $\mathrm{E}$ & 2.5 & 3.30 & $\mathrm{E}$ & 3 \\
\hline $\begin{array}{l}\text { Social media can assure that customers can stay updated } \\
\text { to the latest development of the business and participate } \\
\text { in campaigns and activities of their choice. }\end{array}$ & 3.27 & $\mathrm{E}$ & 1.5 & 2.90 & $\mathrm{E}$ & 4.5 & 3.08 & $\mathrm{E}$ & 4.5 \\
\hline $\begin{array}{l}\text { Customer loyalty is established because their concerns } \\
\text { are often given attention through blogs and other form of } \\
\text { feedback mechanism. }\end{array}$ & 3.25 & $\mathrm{E}$ & 3 & 2.90 & $\mathrm{E}$ & 4.5 & 3.08 & $\mathrm{E}$ & 4.5 \\
\hline $\begin{array}{l}\text { Through social media, the company is able to showcase } \\
\text { other facilities and amenities, other than product that the } \\
\text { paying public receive and decide to purchase. }\end{array}$ & 3.20 & $\mathrm{E}$ & 4.5 & 2.70 & $\mathrm{E}$ & 6 & 2.95 & $\mathrm{E}$ & 6 \\
\hline $\begin{array}{l}\text { Social media is a means to interact and reward loyal } \\
\text { customers. }\end{array}$ & 3.09 & $\mathrm{E}$ & 7 & 2.50 & $\mathrm{E}$ & 7 & 2.79 & $\mathrm{E}$ & 7 \\
\hline Composite mean & 3.21 & $\mathrm{E}$ & & 3.09 & $\mathrm{E}$ & & 3.15 & $\mathrm{E}$ & \\
\hline
\end{tabular}

Table 7 shows that both respondents perceived that social media is effective with regards to customer loyalty perceived by the owners and customers having a composite mean of 3.15. Social media is effective in generating interaction that can maintain a good and long - term relationship with customers with weighted mean of 3.48. Restaurants perceived that it is highly effective because they can know that the customers' requirements are and comply with it. It can be what they want, fast responses and an excellent online customer service (Callarisa, Garcia, Cardiff, \& Roshchina, 2012). On the other hand, customers view it as effective. They don't see social media as the only basis of their loyalty to a business. An article by Miriam C. states list of ways to develop a loyal restaurant customer and it is all about the services during the actual dining experience and rewards the customer receives. Good PR wouldn't make the customers stay for long, good product and restaurant service is needed.

Through social media, there's an opportunity to strengthen the relationship between a company and its customers, weighted mean of 3.30. There will be an open communication between the two and this can start a harmonious relationship. Ranked last but still effective 'social media is a means to interact and reward loyal customers', weighted mean of 2.79. This is another way to communicate with loyal customers personally. They can also promote promos that only online users can avail like what Assenov and Khurana suggested (Assenov et al., 2012). They also mentioned that this will help to retain loyal customers and promote the brand at the same time.

Table 8

Summary table on the effectiveness of social media

\begin{tabular}{|c|c|c|c|c|c|c|c|c|c|c|}
\hline \multirow{2}{*}{\multicolumn{2}{|c|}{ Times }} & \multicolumn{3}{|c|}{ Customer } & \multicolumn{3}{|c|}{ Owner } & \multicolumn{3}{|c|}{ Over-all } \\
\hline & & WM & VI & $\mathrm{R}$ & WM & VI & $\mathrm{R}$ & WM & VI & $\mathrm{R}$ \\
\hline Market Share/ Customer Generation & & 3.31 & E & 1 & 3.24 & $\mathrm{E}$ & 1 & 3.27 & $\mathrm{E}$ & 1 \\
\hline Sales/ Profit Growth & & 3.16 & $\mathrm{E}$ & 4 & 2.89 & $\mathrm{E}$ & 3 & 3.02 & $\mathrm{E}$ & 3 \\
\hline Customer Service and Satisfaction & & 3.19 & $\mathrm{E}$ & 3 & 2.77 & $\mathrm{E}$ & 4 & 2.98 & $\mathrm{E}$ & 4 \\
\hline Customer Loyalty & & 3.21 & $\mathrm{E}$ & 2 & 3.09 & $\mathrm{E}$ & 2 & 3.15 & $\mathrm{E}$ & 2 \\
\hline & Composite mean & 3.22 & $\mathrm{E}$ & & 3.00 & $\mathrm{E}$ & & 3.11 & $\mathrm{E}$ & \\
\hline
\end{tabular}

Table 8 presents the summary of the effectiveness of social media perceived by the owners and customers having a composite mean of 3.11 percent. Social media is effective with regards to market share, customer loyalty, sales, and customer service and satisfaction with a weighted mean of 3.27, 3.11, 3.02, and 2.98 
Manalo, S.

respectively. Social Media is a very effective way to promote a business. It has the ability to communicate with others without limitations (Tardanco, 2012). It can also attract customers that cannot be reached by using traditional marketing. It is more costly to generate new customers than to retain them. But the result of this paper agreed that it is more effective to use social media to generate new customers than to retain them. But then, cost is not part of the issue anymore because as what Nassar (2012) stated, any firm can potentially benefit from Social Media in generating brand reputation and enabling faster audience reach in a cost-effective manner.

Colliander and Dehlén (2011) stressed that companies now use social media to gather information and gain loyal customers. When the business already gains customers and marketplace intelligence that is when the sales start to increase. Marketers also showed the conclusion that is a need to gain the trust of customers first before a business expects an increase in its sales. The result of the study shows that social media is an effective way to clearly understand customers and satisfy their needs. They need excellent customer service (Callarisa et al., 2012). Some type of customer service can be fulfilled online but others need to be done in person.

\section{Table 9}

Problems encountered in social media

\begin{tabular}{|c|c|c|c|c|c|c|c|c|c|}
\hline \multirow{2}{*}{ Times } & \multicolumn{3}{|c|}{ Customer } & \multicolumn{3}{|c|}{ Owner } & \multicolumn{3}{|c|}{ Over-all } \\
\hline & WM & VI & $\mathrm{R}$ & WM & VI & $\mathrm{R}$ & WM & VI & $\mathrm{R}$ \\
\hline $\begin{array}{l}\text { Social media is being accessed by everyone, so } \\
\text { complaints can be publicly revealed. }\end{array}$ & 3.19 & $\mathrm{O}$ & 1 & 2.7 & $\mathrm{O}$ & 1 & 2.94 & $\mathrm{O}$ & 1 \\
\hline People trust social media too much. & 3.07 & $\mathrm{O}$ & 4 & 2.5 & $\mathrm{O}$ & 2 & 2.79 & $\mathrm{O}$ & 2 \\
\hline $\begin{array}{l}\text { Social media can possibly destroy one's image and } \\
\text { reputation. }\end{array}$ & 3.14 & $\mathrm{O}$ & 2 & 2.4 & $S$ & 3 & 2.77 & $\mathrm{O}$ & 3 \\
\hline $\begin{array}{l}\text { Social media can attract negative users including } \\
\text { spammers, scammers, posers and bashers }\end{array}$ & 3.11 & $\mathrm{O}$ & 3 & 2.2 & $S$ & 7 & 2.66 & $\mathrm{O}$ & 4 \\
\hline $\begin{array}{l}\text { Social media can be a way to news jacking/ piracy of } \\
\text { ideas. }\end{array}$ & 3.01 & $\mathrm{O}$ & 6 & 2.3 & $S$ & 4.5 & 2.65 & $\mathrm{O}$ & 5 \\
\hline $\begin{array}{l}\text { If not careful enough, confidential/private information } \\
\text { can be accidentally released. }\end{array}$ & 3.05 & $\mathrm{O}$ & 5 & 2.2 & S & 7 & 2.63 & $\mathrm{O}$ & 6 \\
\hline $\begin{array}{l}\text { In social media consumers are not always presented a } \\
\text { good representation of the opinions, thoughts and } \\
\text { expressions because only the popular social media sites } \\
\text { are represented well in the internet. }\end{array}$ & 2.98 & $\mathrm{O}$ & 7.5 & 2.2 & $\mathrm{~S}$ & 7 & 2.59 & $\mathrm{O}$ & 7 \\
\hline Social media is a way to spread bad publicity. & 2.98 & $\mathrm{O}$ & 7.5 & 2.1 & $S$ & 10 & 2.54 & $\mathrm{O}$ & 8 \\
\hline $\begin{array}{l}\text { Social media can also lead to unfair negativity, } \\
\text { inaccurate information and undue criticism }\end{array}$ & 2.97 & $\mathrm{O}$ & 9 & 2.1 & $S$ & 10 & 2.54 & $\mathrm{O}$ & 9 \\
\hline $\begin{array}{l}\text { Social media account are not maintained/updated } \\
\text { regularly. }\end{array}$ & 2.73 & $\mathrm{O}$ & 16 & 2.3 & $\mathrm{~S}$ & 4.5 & 2.52 & $\mathrm{O}$ & 10 \\
\hline Social media can create a platform for cyber bullying. & 2.97 & $\mathrm{O}$ & 10 & 2.0 & S & 12.5 & 2.48 & $\mathrm{~S}$ & 11 \\
\hline $\begin{array}{l}\text { Web sites can be harmful to the success of a single } \\
\text { form or industry segment. }\end{array}$ & 2.77 & $\mathrm{O}$ & 15 & 2.1 & $S$ & 10 & 2.43 & $\mathrm{~S}$ & 12 \\
\hline Social media holds your business as you go online. & 2.82 & $\mathrm{O}$ & 13.5 & 2.0 & $\mathrm{~S}$ & 12.5 & 2.41 & $\mathrm{~S}$ & 13 \\
\hline $\begin{array}{l}\text { Social media can be possibly abused by the tourist and } \\
\text { employees in exposing an employer's trade secrets or } \\
\text { business proprietary information. }\end{array}$ & 2.84 & $\mathrm{O}$ & 12 & 1.9 & $S$ & 14 & 2.37 & $\mathrm{~S}$ & 14 \\
\hline Social media can spread false information like wildfire. & 2.85 & $\mathrm{O}$ & 11 & 1.8 & S & 15 & 2.33 & $\mathrm{~S}$ & 15 \\
\hline $\begin{array}{l}\text { Companies find ways to abuse social media without } \\
\text { anyone truly knowing and without any real } \\
\text { consequences. }\end{array}$ & 2.82 & $\mathrm{O}$ & 13.5 & 1.7 & $\mathrm{~S}$ & 16 & 2.26 & $\mathrm{~S}$ & 16 \\
\hline Composite mean & 2.96 & $\mathrm{O}$ & & 2.16 & S & & 2.56 & $\mathrm{O}$ & \\
\hline
\end{tabular}

Table 9 presents the problems encountered by both respondents in SM with composite mean of 2.56. With a WM of 2.94, they both often encountered situations that SM can be accessed by everyone. Complaints and unwanted posts can be publicly revealed. According to Mahmood et. al., once information has been leaked into the cyber space (Mahmood et al., 2010), that information is impossible to hold back and the business can only take responsibility for it. Ones it is posted, almost everyone will believe in it. This is also another problem that the respondents often encountered. With a WM of 2.79, people trust social media too much and other establishments take this opportunity to create bad reputation for their competitors. Nowadays, even unreliable 
source can make people believe what they want them to believe.

Those bad reputation can then possible destroy one's image and reputation, WM of 2.77. Social media provides a whole new platform for which it builds or destroys an industry. Horvath shared that what used to be months or years is now only a matter of hours to destroy a reputation (Horvath, 2014). The respondents sometimes encountered problems in social media like: cyber bullying, 2.48; harm the success of a single form or industry segment, 2.43; holds business as you go online, 2.41; abuse by tourists and employees in exposing secret information, 2.37; spread false information,2.33; and abuse by companies, 2.26.

Cyber bullying is associated with spreading false information, information that can harm people. As for some people can share false information from testimonials of personal confrontation that sometimes are already altered base on the writers' emotion toward the business. People reading the false information will have a bad impression of the business and they will start to condemn it without even hearing the side of the other party. Power is often abused by people whose holding it. Information is power. It is being used for personal gain even if it can destroy others. The issue about privacy is adamant to stay. But exposing trade secret does not happen. People are still afraid to get sued for spreading confidential information. It is the same with spreading false information to the public which usually ends to people suing each other.

\section{Table 10}

Difference on the respondents' effectiveness of social media between the two groups

\begin{tabular}{|c|c|c|c|c|c|c|}
\hline Items & group & $N$ & Mean & $t$-value & $p$-value & Interpretation \\
\hline \multirow[t]{2}{*}{ Market share } & Customers & 180 & 3.31 & \multirow{2}{*}{0.268} & \multirow{2}{*}{.794} & \multirow{2}{*}{ Not Significant } \\
\hline & Owners & 10 & 3.24 & & & \\
\hline \multirow[t]{2}{*}{ Sales } & Customers & 180 & 3.16 & \multirow{2}{*}{0.720} & \multirow{2}{*}{.489} & \multirow{2}{*}{ Not Significant } \\
\hline & Owners & 10 & 2.89 & & & \\
\hline \multirow{2}{*}{$\begin{array}{l}\text { Customer service and } \\
\text { satisfaction }\end{array}$} & Customers & 180 & 3.19 & \multirow{2}{*}{1.079} & \multirow{2}{*}{.308} & \multirow{2}{*}{ Not Significant } \\
\hline & Owners & 10 & 2.77 & & & \\
\hline \multirow[t]{2}{*}{ Customer loyalty } & Customers & 180 & 3.21 & \multirow{2}{*}{0.363} & \multirow{2}{*}{.725} & \multirow{2}{*}{ Not Significant } \\
\hline & Owners & 10 & 3.09 & & & \\
\hline
\end{tabular}

Table 10 reveals that all computed p-values are all greater than .05 alpha level, thus the null hypothesis of no significant difference on the effectiveness of SM between the two groups of respondents is accepted. This means that both respondents have the same observation and point of view on the effectiveness of SM. They also both agree that SMM is effective in the restaurant industry.

The study of Nassar (2012) proves the power of social media to people. Consumers had been previously swayed by businesses and marketers. However, nowadays, their purchasing decisions are influenced largely by their social circles. This is supported by the study of Hinz, Schulze, and Takac (2014); Ma, Krishnan, and Montgomery (2014); and Palmer and Ponsonby (2002).

\section{Table 11}

Difference of respondents on the problems encountered on social media between the two groups

\begin{tabular}{clccccc}
\hline Items & group & $N$ & Mean & \multirow{2}{*}{-value } & $p$-value & Interpretation \\
\hline \multirow{2}{*}{ Problems encountered } & Customers & 180 & 3.31 & \multirow{2}{*}{3.781} & \multirow{2}{*}{.000} & \multirow{2}{*}{ Highly significant } \\
& Owners & 10 & 3.09 & \multirow{2}{*}{$*$} & & \\
\hline
\end{tabular}

As shown by table 11, the p-value of .000 is less than .05 alpha level, therefore the null hypothesis is rejected. This means that the problems encountered by both respondents are different from one another. The problems encountered by customers are significantly higher than restaurants.

They both agree that they often encountered problems like; everyone seeing everything they post, and trusting other people's post which results to attracting negative people and possibly destroy an establishment's reputation. In terms of the problems that the establishment is responsible of, that is where they totally disagree 
Manalo, S.

with each other like not maintaining or updating the site regularly. As an establishment's point of view, they will never admit that they lack on some areas or that they do not notice that problems which start to grow in their business.

\section{Table 12}

Proposed marketing strategy

\begin{tabular}{|c|c|c|}
\hline Objectives & Strategies & Outcomes \\
\hline $\begin{array}{l}\text { To supervise the } \\
\text { complaints that is being } \\
\text { publicly revealed. }\end{array}$ & $\begin{array}{l}\text { Designate personnel to answer the complaint as } \\
\text { soon as it arrives. }\end{array}$ & $\begin{array}{l}\text { The customers will be satisfied because } \\
\text { they know that the business hear their } \\
\text { complaints }\end{array}$ \\
\hline $\begin{array}{l}\text { To take advantage of } \\
\text { people's trust to social } \\
\text { media. }\end{array}$ & $\begin{array}{l}\text { Advertise more on social media and level up } \\
\text { media promotions to gain public trust. }\end{array}$ & $\begin{array}{l}\text { The business will gain public trust and } \\
\text { there will be an increase of customers } \\
\text { and sales. }\end{array}$ \\
\hline $\begin{array}{l}\text { To prevent the destruction } \\
\text { of one's image and } \\
\text { reputation. }\end{array}$ & $\begin{array}{l}\text { Designate personnel to answer the complaint as } \\
\text { soon as it arrives so that it won't get bigger and } \\
\text { damage reputation of the company. }\end{array}$ & $\begin{array}{l}\text { The business will know as soon as a } \\
\text { problem occurs. They can also resolve it } \\
\text { before causing any trouble for the } \\
\text { establishment. }\end{array}$ \\
\hline $\begin{array}{l}\text { To control the flow of } \\
\text { negative users including } \\
\text { spammers, scammers, } \\
\text { posers and bashers }\end{array}$ & $\begin{array}{l}\text { Fix the conflict between the business and the } \\
\text { negative user. Show the establishment's integrity } \\
\text { to the customers. It can be by sharing customer's } \\
\text { comments and recommendations. }\end{array}$ & $\begin{array}{l}\text { The negative users will lessen and can } \\
\text { also turn to customers. }\end{array}$ \\
\hline $\begin{array}{l}\text { To avoid news jacking } \\
\text { (stealing mindshare from a } \\
\text { trending news or event)/ } \\
\text { piracy of ideas. }\end{array}$ & $\begin{array}{l}\text { Submit or apply for a patent or copyright for the } \\
\text { idea to prevent others from keeping the idea as } \\
\text { their own }\end{array}$ & $\begin{array}{l}\text { The piracy of ideas will be } \\
\text { lessened/stopped }\end{array}$ \\
\hline
\end{tabular}

\section{References}

Adler, E. (2014). The race among social networks for engagement and time spend has created new winners and losers. Business Insider.

Akram, W., \& Kumar, R. (2017). A study of positive and negative effects of social media on society. International Journal of Computer Sciences and Engineering, 5(19), 347-354. https://doi.org/10.26438/ijcse/v5i10.351354

Anderson, C. K. (2012). The impact of social media on lodging performance. Cornell Hospitality Report, 12(15), 6-11.

Assenov, I., \& Khurana, N. (2012). Social media marketing and the hospitality industry: Evidence from Thailand. In the Proceedings of the 2012 International Conference on Business and Management (pp. 325-335).

Bhanot, S. (2012), Use of social media by companies to reach their customers. SIES Journal of Management, $8(1), 47-55$.

Bredican, J., \& Vigar-Ellis, D. (2014). Smartphone applications-idea sourcing and app development: Implications for firms. South African Journal of Economic and Management Sciences, 17(3), 232-248. https://doi.org/10.4102/sajems.v17i3.492

Callarisa, L., García, J. S., Cardiff, J., \& Roshchina, A. (2012). Harnessing social media platforms to measure customer-based hotel brand equity. Tourism Management Perspectives, 4, 73-79. https://doi.org/10.1016/j.tmp.2012.04.005

Colliander, J., \& Dahlén M. (2011). Following the fashionable friend: The power of social media weighing publicity effectiveness of blogs versus online magazines. Journal of Adverting Research, 51, 313-320. https://doi.org/10.2501/JAR-51-1-313-320

Coombs, W. T., \& Holladay, J. S. (2012). The paracrisis: The challenges created by publicly managing crisis prevention. Public Relations Review, 38(3), 408-415. https://doi.org/10.1016/j.pubrev.2012.04.004

CSPOnline. (2016). The importance of marketing in the hospitality industry. Concorida St. Paul.

Debono, R. (2013). The effectiveness of social media marketing as a branding tool for hoteliers. University of Malta.

Derani, N., \& Naidu, P. (2015). The impact of utilizing social media as a communication platform during a crisis 
within the oil industry. Procedia Economics and Finance, 35, 650-658. https://doi.org/10.1016/S2212-5671(16)00080-0

Digital Marketing Institute. (n.d.). 9 ways digital has change business forever. Digital Marketing Institute.

Dina, R., \& Sabou, G. (2012). Influence of social media in choice of tourist destination. Cactus Tourism Journal, 3(2), 24-30.

Faria, W., \& Elliot, S. (2012). Understanding the role of social media in destination marketing. Tourismos: An International Multidisciplinary Journal of Tourism, 7(1), 193-211.

Fotis, J., Buhalis, D., \& Rossides, N., (2012). Social media use and impact during the holiday travel planning process. In the Proceedings of the 2012 Information and Communication Technologies in Tourism (pp. 13-24). Springer. https://doi.org/10.1007/978-3-7091-1142-0_2

Hinz, O., Schulze, C., \& Takac, C. (2014). New product adoption in social networks: Why direction matters. Journal of Business Research, 67(1), 2836-2844. https://doi.org/10.1016/j.jbusres.2012.07.005

Horvath, B. (2014). Reputations, trolls, and the internet. Business 2 Business.

Iacianci, C. M. (2015). Hotel manager's attitudes toward social media. Kent State University College.

Kietzmann, J. H., Hermkens, K., McCarthy, I. P., \& Silvestre, B. S. (2011) Social media? Get serious! Understanding the functional building blocks of social media. Business Horizons 54(3) 241-251. https://doi.org/10.1016/j.bushor.2011.01.005

Kim, A., \& Ko, E. (2010). Impacts of luxury fashion brand's social media marketing on customer relationship and purchase intention. Journal of Global Fashion Marketing, 1(3), 164-171. https://doi.org/10.1080/20932685.2010.10593068

Koroma, U. (2012). The effectiveness of social media in event marketing. University of Applied Science.

Lee, M. K., Verma, R., \& Roth, A. (2015). Understanding customer value in technology enabled services: A numerical taxonomy based on usage and utility. Service Science, 7(3), 227-248. https://doi.org/10.1287/serv.2015.0105

Ma, L., Krishnan, R., \& Montgomery, A. L. (2014). Latent homophily or social influence? An empirical analysis of purchase within a social network. Management Science, 61(2), 454-473. https://doi.org/10.1287/mnsc.2014.1928

Mahmood, M. A., Siponen, M., Straub, D., Rao, H. R., \& Raghu, T. (2010). Moving toward black hat research in information systems security: An editorial introduction to the special issue. MIS Quarterly, 34(3), 431-433. https://doi.org/10.2307/25750685

Metev, D. (2020). How much time do people spend on social media? Review 42.

Miriam, C. (n.d.). How to develop a loyalty in a restaurant business. Houston Chronicle.

Nassar, M. A. (2012). An investigation of Hotelier's attitudes towards the use of social media as a branding tool. International Journal of Marketing studies, 4(4), 93-105. https://doi.org/10.5539/ijms.v4n4p93

Odden, L. (2011). Social media and SEO: Five essential steps to success. Weblog post. Mashable.

Osatuyi, B. (2015). Personality traits and information privacy concern on social media platform. Journal of Computer Information System, 55(4), 11-19. https://doi.org/10.1080/08874417.2015.11645782

Palmer, A., \& Ponsonby, S. (2002). The social construction of new marketing paradigms: The influence of personal perspective. Journal of Marketing Management, 18(1-2), 173-192. https://doi.org/10.1362/0267257022775864

Rathonyi, G. (2013). Influence of social media on tourism: Especially among students of the University of Debrecen. Applied Studies in Agribusiness and Commerce, 7(1), 105-112. https://doi.org/10.19041/Apstract/2013/18

Singh, A., \& Dev, C. (2014). A flow-through analysis of the US lodging industry during the great recession. Cornell University, SHA School. https://doi.org/10.1108/IJCHM-12-2012-0260

Sparks, B., \& Browning, V. (2011). The impact of online reviews on hotel booking intentions and perceptions of trust. Journal of Tourism Management, 32, 1310-1323. https://doi.org/10.1016/j.tourman.2010.12.011

Torres, E. N., \& Kline, S. (2016). From satisfaction to delight: A model for the hotel industry. International Journal of Contemporary Hospitality Management, 18, 290-301. https://doi.org/10.1108/09596110610665302 
Manalo, S.

Verma, R., Stock, D., \& McCarthy, L. (2012). Customer preferences for online, social media, and mobile innovations in the hospitality industry. Cornell Hospitality Quarterly, 53(3), 183-186.

https://doi.org/10.1177/1938965512445161

Zucal, C. (2012). Social media: The open door to brand loyalty.

http://socialmediatoday.com/caitlinz10/948696/social-media-open-door-brand-loyalty 